\title{
Komik Fotokopian Indonesia 1998 - 2001
}

\author{
Imansyah Lubis \\ Program Magister Seni Rupa \\ Fakultas Seni Rupa dan Desain Institut Teknologi Bandung
}

\begin{abstract}
Comics have become an integrated part in Indonesian history. It also has a good prospect to continuously growing in modern media. As one of the medium of free expression, Indonesian comics has been experiencing its ups and downs over several decades. The growth of photocopied comics in Indonesia in year 1990s has become one of the important phases of a whole Indonesian comics development and movement. As a milestone, it is interesting to know further about the contexts of these photocopied comics. The main sources for this research are the photocopied comics collected by writer himself, and thereby this research only focused at a specific period of time between the years 1998 to 2001. Data being analyzed includes the internal contexts of comic, consisted of its 'soul' (theme, story, casting, and story background), and its 'body' (illustration), and the external contexts (illustrators, production - distribution, and readers). One of the challenges in doing this research is that not all of the photocopied comics mentioned what year it is being published. However, those comics are still analyzed considering they are in the same timeline with the rest. Writer is also perforced to exclude some comics, because they were not photocopied, but printed. This research tries to keep its focus to internal and external contexts of these photocopied comics, with sociological and anthropological approach.As a general conclusion, it can be said that social mind theme and theme from photocopied comics are complementary one another. Humor comic type and men gender comic figure from middle-weight predominates, so do with urban setting. The influence of manga visual style can be easily found, and most of comics' creators are men who lived in Jakarta.By the end of this article, the author projects Indonesian comics prospect - not only its photocopied ones - in the future.
\end{abstract}

Keywords: anthropology; comics; communications contexts; media; photocopy; photocopied; sociology.

\section{$1 \quad$ Pendahuluan}

Perkembangan gambar sebagai simbol non verbal untuk mengungkapkan pikiran dan perasaan telah berkembang sejak zaman prasejarah hingga saat ini. Sebelum bahasa tulisan ditemukan, gambar-gambar yang bersifat sekuensial telah dimanfaatkan sebagai media pendidikan dan transfer tradisi oleh para tetua kepada generasi berikutnya. Komik merupakan salah satu media komunikasi yang identik dengan gambar. 
Saat ini komik hampir tidak terpisahkan dari keseharian kita, dengan kemampuannya menyampaikan informasi secara efektif dan efisien melalui bahasanya sendiri. Meskipun komik memberi kesempatan berekspresi secara verbal dan visual, sebagai media seni komik tetap berada dalam batas-batas komunikasi. Walaupun demikian, tanpa pengertian mendalam tentang gaya komik sebagai ekspresi seni, komik tidak dapat dinilai dengan tepat dan layak.

Sebagai sebuah media ekspresi seni, komik tidak dapat dengan semena-mena melepaskan diri begitu saja dari pembacanya sebagai konsumen. Pola produksi dan konsumsi komik pun berkembang seiring dengan dinamika masyarakat dan perkembangan teknologi. Kesempatan untuk mengembangkan dunia gambar melalui bahasa komik senantiasa terbuka lebar.

Hal ini dimanfaatkan sepenuhnya oleh para seniman. Dengan cara dan gayanya masing-masing, mereka memanfaatkan media komik dan membahasakannya sesuai dengan selera masing-masing. Hasilnya bisa dilihat dengan amat beragamnya komik yang hadir. Tidak hanya pada tampilan visualnya, namun juga pada media yang membawanya.

Seperti telah kita ketahui bersama, komik Indonesia pernah mengalami masa jayanya. Seiring dengan semakin terpuruknya komik Indonesia akibat invasi dan dominasi komik asing, gerakan bersama untuk merevitalisasi kejayaan ini merupakan hal yang pelik karena banyaknya kendala dari tiga komponen: produsen (dalam hal ini, pembuat komik), penerbit, dan pembaca.

Kurang optimalnya etos kerja menjadi kendala utama dari pihak produsen komik. Hal ini terjadi karena sedikit sekali komikus yang benar-benar mengerjakan komik secara professional. Pekerjaan utama komikus saat ini berkisar di antara perkuliahan, periklanan, desain, dan ilustrasi. Bahkan beberapa komikus dari generasi terdahulu pun berpindah jalur penghidupan, karena menganggap nafkah yang didapat dari jalur non komik lebih mencukupi kebutuhannya. Pertimbangan segi kuantitas dan (terutama) kualitas pun menyebabkan sulitnya sebuah komik dapat diproduksi dan terbit secara berkesinambungan. Hal ini diperburuk dengan terbatasnya sarana, prasarana, dan kesempatan bagi komik Indonesia untuk tampil.

Sebagian besar anggota masyarakat pun masih memandang komik sebagai sesuatu yang rendah dan buruk. Yang paling sering: komik hanya bacaan bagi anak-anak. Hal ini bagaikan membatasi kreativitas para produsen komik lokal. Namun dapat dimaklumi, karena pada kenyataannya Indonesia memang pernah dibanjiri oleh sedemikian banyak komik yang hanya mengejar tiras tanpa memperhitungkan kualitas isinya, hingga pada akhirnya dilakukan Operasi 
Tertib Remaja (OpsTerMa) terhadap komik Indonesia pada tahun 1970. Hal ini amat mempengaruhi kondisi perkomikan Indonesia.

Para penerbit pun akhirnya tidak mau mengambil resiko rugi dengan menerbitkan komik Indonesia, yang (menurut mereka) belum tentu berkualitas. Sikap selektif (yang terkadang agak berlebihan) ini mengakibatkan sulitnya para komikus lokal untuk mencari mitra bisnis demi eksistensi komik Indonesia. Jika diterima pun, pihak komikus hanya menerima harga yang relatif rendah bila dibandingkan dengan biaya produksi yang dikeluarkan. Distribusinya pun amat terbatas. Walhasil, para komikus sulit mematok harga rendah bagi komik produksi mereka.

Tentunya insan komik Indonesia tidak diam saja. Masih ada jalur yang bisa ditempuh untuk tetap bisa berkarya, yaitu jalur underground. Gerakan komik underground yang dimulai di Amerika Serikat sejak tahun 1960-an dan berkembang di Eropa sejak pertengahan tahun 1970-an menjadi salah satu bukti nyata akan keberagaman dunia komik, yang imbasnya pun terasa hingga ke Indonesia.

Pada pertengahan tahun 1990-an, dunia perkomikan Indonesia dibanjiri oleh komik-komik yang diperbanyak dengan cara fotokopi dan diedarkan dari tangan ke tangan sesuai dengan permintaan 'pasar' (yang notabene lebih banyak teman-teman sesama peminat komik dan sesama komikus). Konvensional, namun efektif dan efisien. Meskipun keuntungan finansial yang diperoleh tidak begitu besar, dengan cara seperti ini para komikus underground sebagai seniman komik sedikit demi sedikit mulai mengukuhkan eksistensinya dan semakin mematangkan gaya mereka dalam mencari wajah komik Indonesia yang hilang. Dalam pergerakan ini, kota-kota seperti Jakarta, Bandung, dan Yogyakarta menjadi motor yang seakan tidak pernah kehabisan energi kreatifnya. Begitu banyaknya komik-komik underground yang dihasilkan dari seniman-seniman dan atau kelompok-kelompok komik yang berdomisili di tiga kota tersebut, namun demikian tidak berarti bahwa komik-komik dari kota-kota lain di Indonesia menjadi kalah penting karenanya.

\section{Sekilas Sejarah Komik Indonesia}

\subsection{Asal-usul Komik Indonesia}

Di Indonesia, cikal bakal komik banyak dipengaruhi oleh agama Budha, Hindu dan Islam. Indikasi ditemukannya lukisan di dinding Gua Leang-Leng di Sulawesi Selatan berupa gambar babi hutan, juga candi-candi sekitar abad ke-18 serta didapatinya gambar-gambar kuno di atas kertas dengan tinta berwarna, yang menyerupai komik. Gambar-gambar sekuensial ini disertai keterangan teks 
beraksara Arab dalam bahasa Jawa, yang dipakai dalam penyebaran agama Islam.

Di Bali, komik dibuat diatas daun lontar, bercerita tentang Dampati Lelangon atau Dharma Lelangon dalam aksara Bali berbahasa Jawa kuno. Di candi-candi Borobudur dan Prambanan terdapat relief yang menceritakan kehidupan spritual dan kebudayaan pada abad pertengahan, juga kita kenal dalam cerita wayang beber dan wayang kulit yang menjadi kesenian masyarakat Jawa menjadi referensi timbulnya komik Indonesia.

\subsection{Generasi 1930-an}

Merujuk kepada Bonneff [1], maka komik Indonesia pada awal kelahirannya dapat di bagi menjadi dua kategori besar, yaitu komik strip dan buku komik. Kehadiran komik-komik di Indonesia pada tahun 1930-an dapat ditemukan pada media Belanda seperti De Java Bode dan D'Orient dimana terdapat komikkomik seperti Flippie Flink and Flash Gordon.

Put On, seorang peranakan Tionghoa adalah karakter komik Indonesia yang pertama-tama merupakan karya Kho Wang Gie yang terbit rutin di surat kabar Sin Po. Selain Bonneff, Arswendo Atmowiloto pun sepakat bahwa sejarah komik modern Indonesia dimulai pada hari Sabtu, tanggal 02 Agustus 1930, dengan tampilnya komik strip katya Kho Wang Gie dalam surat kabar Sin Po tersebut. Pada awalnya, serial strip yang dimuat seminggu sekali ini menceritakan berbagai petualangan tokoh jenaka. Baru pada tanggal 17 Januari 1931 Kho Wang Gie menciptakan tokoh tetap bernama Put On. Put On menginspirasi banyak komik strip lainnya sejak tahun 30-an sampai 60-an seperti pada majalah Star (1939-1942) yang kemudian bertukar menjadi Star Weekly.

Sementara itu di Solo, Nasroen A. S. membuahkan karya komik stripnya yang berjudul Mentjcari Poetri Hidjaoe melalui mingguan Ratu Timur. Di awal tahun 1950-an, salah satu pionir komik bernama Abdulsalam menerbitkan komik strip heroiknya di harian Kedaulatan Rakyat, Yogyakarta, salah satunya berjudul "Kisah Pendudukan Jogja", bercerita tentang agresi militer Belanda ke atas kota Yogyakarta. Komik ini kemudian dibukukan oleh harian "Pikiran Rakyat" dari Bandung. Sebagian pengamat komik berpendapat bahwa inilah buku komik pertama-tama oleh artis komik Indonesia.

\subsection{Generasi 1940-an hingga 1950-an}

Sekitar akhir tahun 1940-an, banyak komik-komik dari Amerika yang disisipkan sebagai suplemen mingguan surat kabar. Diantaranya adalah komik seperti Tarzan, Rip Kirby, Phantom and Johnny Hazard. Kemudian penerbit 
seperti Gapura dan Keng Po dari Jakarta, serta Perfects dari Malang, mengumpulkannya menjadi sebuah buku komik.

Di tengah-tengah membanjirnya komik-komik asing, hadir Siaw Tik Kwie, salahs seorang komikus garda depan, yang memiliki teknik dan keterampilan tinggi dalam menggambar mendapatkan kesempatan untuk menampilkan komik adapatasinya dari legenda pahlawan Tiongkok 'Sie Djin Koei'. Komik ini berhasil melampaui popularitas Tarzan di kalangan pembaca lokal. Popularitas tokoh-tokoh komik asing mendorong upaya mentransformasikan beberapa karakter pahlawan super itu ke dalam selera lokal. R.A. Kosasih, yang kemudian dikenal sebagai Bapak Komik Indonesia, memulai karirnya dengan mengadaptasi Wonder Woman menjadi pahlawan wanita bernama Sri Asih. Terdapat banyak lagi karakter pahlawan super yang diciptakan oleh komikus sezaman lainnya, diantaranya adalah Siti Gahara, Puteri Bintang, Garuda Putih dan Kapten Komet, yang mendapatkan inspirasi dari Superman dan petualangan Flash Gordon.

\subsection{Generasi 1960-70an}

Adapatasi dari komik asing dalam komik Indonesia mendapatkan tentangan dan kritikan dari kalangan pendidik dan pengkritik budaya. Karena itu penerbit seperti Melodi dari Bandung dan Keng Po dari Jakarta mencari orientasi baru dengan melihat kembali kepada khazanah kebudayaan nasional. Sebagai hasil pencarian itu maka cerita-cerita yang diambil dari wayang Sunda dan Jawa menjadi tema-tema prioritas dalam penerbitan komik selanjutnya. R.A. Kosasih adalah salah seorang komikus yang terkenal keberhasilannya membawa epik Mahabharata dari wayang ke dalam media buku komik.

Sementara itu dari Sumatra, terutamanya di kota Medan, terdapat pionir-pionir komikus berketerampilan tinggi seperti Taguan Hardjo, Djas, dan Zam Nuldyn, yang menyumbangkan estetika dan nilai filosofi ke dalam seni komik. Di bawah penerbitan Casso and Harris, artis-artis komik ini mengeksplorasi cerita rakyat Sumatra yang kemudian menjadi tema komik yang sangat digemari dari tahun 1960-an hingga 197-0an.

Generasi ini banyak dipengaruhi komik-komik dengan gaya Amerika, Eropa, dan Tiongkok. Sebagian besar memanfaatkan majalah dan koran sebagai medianya, meskipun beberapa karya seperti Majapahit oleh R.A. Kosasih juga mendapatkan kesempatan untuk tampil dalam bentuk buku. Tema yang banyak muncul adalah pewayangan, adi ksatria (superhero), dan humor-kritik. 


\subsection{Generasi 1990-an hingga 2000-an}

Ditandai oleh dimulainya kebebasan informasi lewat internet dan kemerdekaan penerbitan, komikus mendapat kesempatan untuk mengeksplorasi gayanya masing-masing dengan mengacu kepada banyak karya luar negeri yang lebih mudah diakses. Selain itu, beberapa judul komik yang sebelumnya mengalami kesulitan untuk menembus pasar dalam negeri, juga mendapat tempat dengan maraknya penerbit komik bajakan.

Selain itu beberapa penerbit besar mulai aktif memberikan kesempatan kepada komikus muda untuk mengubah citra komik Indonesia yang selama ini terkesan terlalu serius menjadi lebih segar dan muda. Ada dua aliran utama yang mendominasi komik modern Indonesia, yaitu Amerika (lebih dikenal dengan comics) dan Jepang (dengan stereotype gaya manga).

\section{$3 \quad$ Perkembangan Komik Indie/Underground Indonesia}

Diawali dengan semangat untuk melawan hegemoni komik-komik dari luar Indonesia, pada pertengahan tahun 1990-an muncullah komik-komik independen (lokal). Mencoba tampil berbeda, membuat gaya gambar lebih variatif dan eksperimental. Banyak komikus-komikus indie (independen) mengandalkan mesin fotokopi untuk penggandaan karya-karya mereka. Sistem distribusi paling banyak dilakukan di pameran komik, baik dengan jalan jualbeli atau barter antarkomikus. Tak jarang ada komikus yang menghalalkan karyanya untuk diperbanyak dan disebarluaskan, dengan motto copyleft (lawan dari copyright atau hak cipta). Tentunya tidak untuk tujuan komersil.

Jika komik indie termasuk kategori jenis penerbitan, maka dari segi tema dikenal juga istilah komik underground (bawah tanah/gerilya). Pada umumnya, komik-komik ini bertemakan isu-isu personal, sara, bahkan yang relatif tabu dalam masyarakat seperti seks, kekerasan berlebihan, politis, dan masih banyak lagi. Kebanyakan komik underground akan mengikuti pola penerbitan indie label atau self publishing, tanpa melibatkan penerbit besar (major label) di jalur mainstream.

Hal ini senada dengan apa yang dikatakan komikus Beng Rahadian, bahwa komik indie merupakan antitesis terhadap industrialisasi komik. Selanjutnya Beng menambahkan beberapa kaidah komik indie, yaitu tidak terpukau oleh produksi massal, tidak harus sebuah kerja tim, dan gagasan lebih bersifat personal bahkan cenderung liar. Komik bagi mereka hanya sebagai media penyampaian gagasan, karya lebih jujur karena tidak ada pertimbangan laba dan komoditi. Kadang bebas melintas batasan estetika, moral, dan kultur, juga 
mengadopsi berbagai gaya visual, tema cerita, dan format komik. Hal-hal seperti ini susah diterima penerbit besar.

Walaupun komik indie sudah mulai mengibarkan benderanya bersamaan dengan diadakannya Pasar Seni ITB tahun 1995, bibitnya sudah disemai di Yogyakarta pada tahun 1992 oleh para penggiatnya secara underground. Sapto Raharjo alias Athonk salah satunya. Seniman tato yang mengenyam kuliah di FSR - ISI Yogyakarta itu rajin memfotokopi dan membagi karya komiknya yang bertajuk Daily Land. Ketekunannya membuahkan hasil. Komiknya "Old Skull: In The Garden" memperoleh penghargaan sebagai komik indi terbaik versi KONDE (Komik Indonesia Satu Dekade) 2007.

Dalam perkembangannya, gerakan ini berkembang menjadi sebuah bentuk perlawanan terhadap hegemoni apa saja seputar perkomikan. Berhasil tampil beda, dan senantiasa berusaha mempertahankan perbedaan tersebut. Eksperimen yang terus menerus menghasilkan gaya tersendiri, demikian pula dengan cara bertuturnya. Bahkan sebagai bentuk perlawanan terhadap 'hegemoni' kertas dan buku, mereka menggunakan semua media yang ada seperti tembok untuk mural, kain untuk spanduk dan kertas bekas sebagai poster.

Hingga saat ini, walaupun tidak segegap-gempita pada tahun 1990-an, komikkomik fotokopian masih eksis di dunia perkomikan Indonesia. Apa yang telah dilakukan oleh para komikus indielunderground dengan komik-komik fotokopiannya merupakan langkah positif agar komik lokal kembali mendapat perhatian dari para pencinta komik di Indonesia, dan oleh karenanya amat layak untuk kita apresiasi bersama.

\section{$4 \quad$ Konteks Internal Komik Fotokopian Indonesia}

Dalam pembahasan komik-komik fotokopian Indonesia tahun 1998 - 2001 ini, tentunya pengambilan data dilakukan tanpa menimbang kualitas karya-karya itu sendiri. Yang penulis coba dekati untuk diteliti secara obyektif adalah kecenderungan para komikus dalam berkarya. Karena kurun waktu antara tahun 1998 hingga 2001 relatif sempit, maka hasil penelitian akan dikelompokkan menjadi sebuah periode yang utuh. Dengan demikian diharapkan dapat diperoleh gambaran umum mengenai konteks internal komik-komik tersebut.

\subsection{Jiwa Komik}

\subsubsection{Tema}

Tema dalam hal ini merupakan sesuatu yang menjadi dasar cerita. Dalam hal tertentu, tema sering dapat disinonimkan dengan ide atau tujuan utama cerita. 
Stanton mendefinisikan tema sebagai makna sebuah cerita yang secara khusus menerangkan sebagian besar unsurnya dengan cara yang sederhana [2].

Eksistensi tema amat bergantung kepada unsur-unsur lainnya, karena tema hanya dapat disampaikan secara implisit melalui cerita. Dalam kategorisasi tema komik, penulis memutuskan untuk mengikuti kategorisasi tema novel dari Jakob Sumardjo [3]. Jakob Sumardjo mengklasifikasikan tema menjadi Tema Batin dan Tema Sosial. Tema Batin menekankan permasalahan di dalam diri manusia (internal), sementara Tema Sosial permasalahan di luar diri manusia.

Jika tema batin lebih menyoroti masalah perasaan, pemikiran, kehendak dan pergolakan batin lain dari tokoh-tokohnya, termasuk psikologi, kegoncangan, kepercayaan, dan lain-lain, maka tema social berkaitan erat dengan permasalahan sosial, politik, adat kebiasaan, dan antropologi.

Tema batin lebih universal karena mencoba mengekspresikan kondisi jiwa manusia dalam menghadapi masalah, menyiratkan adanya introspeksi diri manusia sebagai bagian dari semesta alam raya. Namun demikian, tidak menutup kemungkinan adanya harapan dan cita-cita manusia pada umumnya untuk meraih kebahagiaan serta pertentangan nilai-nilai dalam kehidupannya. Tema sosial bersifat lebih kontekstual, karena persoalan sezaman menjadi amat penting sebagai bahan ekspresi utama. Hal ini muncul sebagai reaksi dari kondisi sosial kemasyarakatan yang dirasa kurang atau bahkan tidak menguntungkan bagi kebahagiaan manusia pada umumnya.

Karena dalam setiap komik fotokopian bisa saja terdapat lebih dari satu tema, maka tabel ini merepresentasikan jumlah komik berbanding dengan jumlah tema.

Tabel 1 Perbandingan jumlah komik dan tema dalam komik fotokopian Indonesia 1998 - 2001.

\begin{tabular}{ccccc}
\hline Tahun & $\begin{array}{c}\text { Jumlah } \\
\text { Komik }\end{array}$ & Tema Batin & Tema Sosial & $\begin{array}{c}\text { Jumlah } \\
\text { Tema }\end{array}$ \\
\hline 1998 & 11 & $36(56.25 \%)$ & $28(43.75 \%)$ & $64(100 \%)$ \\
1999 & 33 & $40(43.96 \%)$ & $51(56.04 \%)$ & $91(100 \%)$ \\
2000 & 19 & $22(48.89 \%)$ & $23(51.11 \%)$ & $45(100 \%)$ \\
2001 & 15 & $18(47.37 \%)$ & $20(52.63 \%)$ & $38(100 \%)$ \\
$\begin{array}{c}\text { Antara } 1998- \\
2001\end{array}$ & 30 & $34(50 \%)$ & $34(50 \%)$ & $68(100 \%)$ \\
\hline Total & $\mathbf{1 0 8}$ & $\mathbf{1 5 0 ( 4 9 . 0 2 \% )}$ & $\mathbf{1 5 6 ( 5 0 . 9 8 \% )}$ & $\mathbf{3 0 6 ( 1 0 0 \% )}$ \\
\hline
\end{tabular}

Tema-tema batin yang dominan di antaranya berkisar seputar dialektika kehidupan, cinta, pencarian jati diri, dan nilai moral. Sementara kritik sosial, bahkan anti pemerintah, amat dominan dalam ranah tema sosial. Bisa dilihat 
bahwa secara keseluruhan hanya terdapat perbedaan persentase yang tipis antara tema batin dan tema sosial, jadi bisa disimpulkan bahwa tema batin dan tema sosial komik fotokopian Indonesia tahun 1998 - 2001 tidak saling mendominasi, namun saling melengkapi satu sama lain.

\subsubsection{Cerita}

Forster (1970) mengartikan cerita sebagai sebuah narasi berbagai kejadian yang sengaja disusun berdasarkan urutan waktu, sementara Kenny (1966) mendefinisikannya sebagai peristiwa-peristiwa yang terjadi berdasarkan urutan waktu yang disajikan dalam sebuah karya fiksi [2]. Aspek cerita dalam komik amat esensial, sesuai dengan definisi komik itu sendiri. Meskipun demikian, wajar dan sah adanya jika orang membaca komik karena lebih dahulu tertarik kepada tampilan visualnya.

Tabel 2 Perbandingan jumlah komik dan cerita dalam komik fotokopian Indonesia 1998 - 2001.

\begin{tabular}{|c|c|c|c|c|c|c|}
\hline Cerita & 1998 & 1999 & 2000 & 2001 & $\begin{array}{c}\text { Antara } \\
1998 \text { - } 2001 \\
\end{array}$ & Total \\
\hline Petualangan & $17(13.48 \%)$ & $17(10.83 \%)$ & $12(12.12 \%)$ & $9(10.71 \%)$ & $8(6.45 \%)$ & $63(11.39 \%)$ \\
\hline Fantasi & $6(6.74 \%)$ & $18(11.64 \%)$ & $11(11.11 \%)$ & $8(9.52 \%)$ & $10(8.06 \%)$ & $53(9.58 \%)$ \\
\hline Perang & $5(5.62 \%)$ & $5(3.18 \%)$ & $2(2.02 \%)$ & $5(5.95 \%)$ & $5(4.03 \%)$ & $22(3.98 \%)$ \\
\hline $\begin{array}{l}\text { Kriminal/ } \\
\text { Detektif }\end{array}$ & $1(1.12 \%)$ & $4(2.55 \%)$ & $7(7.07 \%)$ & $1(1.19 \%)$ & $6(4.84 \%)$ & $19(3.44 \%)$ \\
\hline $\begin{array}{c}\text { Kisah } \\
\text { Nyata/ } \\
\text { Biografi }\end{array}$ & $6(6.74 \%)$ & $12(7.64 \%)$ & $8(8.08 \%)$ & $8(9.52 \%)$ & $20(16.13 \%)$ & $54(9.76 \%)$ \\
\hline $\begin{array}{c}\text { Kartun } \\
\text { Binatang }\end{array}$ & $2(2.25 \%)$ & $14(8.92 \%)$ & $2(2.02 \%)$ & $1(1.19 \%)$ & $3(2.42 \%)$ & $22(3.98 \%)$ \\
\hline $\begin{array}{l}\text { Silat/Bela } \\
\text { Diri }\end{array}$ & $13(14.61 \%)$ & $8(5.10 \%)$ & $3(3.03 \%)$ & $1(1.19 \%)$ & $7(5.65 \%)$ & $32(5.79 \%)$ \\
\hline Humor & $15(16.85 \%)$ & $43(27.39 \%)$ & $14(14.14 \%)$ & $18(21.43 \%)$ & $23(18.55 \%)$ & $113(20.43 \%)$ \\
\hline $\begin{array}{l}\text { Cerita } \\
\text { Klasik }\end{array}$ & $2(2.25 \%)$ & $1(0.64 \%)$ & $3(3.03 \%)$ & $5(5.95 \%)$ & $0(0 \%)$ & $11(1.99 \%)$ \\
\hline Roman & $4(4.49 \%)$ & $7(4.46 \%)$ & $7(7.07 \%)$ & $8(9.52 \%)$ & $16(12.90 \%)$ & $42(7.59 \%)$ \\
\hline Sejarah & $2(2.25 \%)$ & $5(3.18 \%)$ & $5(5.05 \%)$ & $7(8.33 \%)$ & $3(2.42 \%)$ & $22(3.98 \%)$ \\
\hline $\begin{array}{l}\text { Misteri/ } \\
\text { Horor }\end{array}$ & $6(6.74 \%)$ & $3(1.91 \%)$ & $9(9.09 \%)$ & $2(2.38 \%)$ & $4(3.23 \%)$ & $24(4.34 \%)$ \\
\hline Keagamaan & $0(0 \%)$ & $0(0 \%)$ & $1(1.01 \%)$ & $0(0 \%)$ & $1(0.81 \%)$ & $2(0.36 \%)$ \\
\hline Fiksi Ilmiah & $3(3.37 \%)$ & $9(5.73 \%)$ & $4(4.04 \%)$ & $6(7.14 \%)$ & $14(11.29 \%)$ & $36(6.51 \%)$ \\
\hline Adi Ksatria & $12(13.48 \%)$ & $11(7.01 \%)$ & $11(11.11 \%)$ & $5(5.95 \%)$ & $4(3.23 \%)$ & $43(7.78 \%)$ \\
\hline Total & $89(100 \%)$ & $157(100 \%)$ & $99(100 \%)$ & $84(100 \%)$ & $124(100 \%)$ & $553(100 \%)$ \\
\hline
\end{tabular}

Jenis cerita komik amat erat kaitannya dengan klasifikasi komik itu sendiri. Tercatat beberapa usaha untuk mengklasifikasikan komik, di antaranya klasifikasi menurut organisasi Child Study Association of America (1943), Asosiasi Majalah Komik Amerika (1971), Herald Vogel (1973), dan Harold 
Schecter (1990). Dalam hal ini penulis akan menggabungkan klasifikasiklasifikasi tersebut untuk memetakan cerita komik fotokopian Indonesia periode 1998 - 2001, seperti dapat dilihat pada Tabel 2.

Seperti halnya dengan tema, dalam setiap komik fotokopian bisa saja terdapat lebih dari satu cerita, maka tabel ini merepresentasikan jumlah komik berbanding dengan jumlah cerita.

Dari Tabel 2, dapat dilihat bahwa jenis komik humor amat dominan. Baik secara keseluruhan maupun per tahun, jenis cerita humor banyak dipilih oleh komikus untuk mengekspresikan ide-idenya dengan tujuan menghibur pembaca. Patut dicatat bahwa kategori humor di sini pun mencakup parodi, satir, dan black comedy, yang biasanya digunakan untuk menyindir pemerintah baik secara halus dan implisit, maupun secara terang-terangan, kasar, dan vulgar.

Sementara cerita-cerita dominan lainnya adalah petualangan, fantasi, kisah nyata/biografi, roman, dan adi ksatria. Menarik untuk dicatat, bahwa ceritacerita yang berhubungan dengan aspek keagamaan amat jarang ditemui dalam komik-komik fotokopian ini. Bisa jadi hal ini dikarenakan cerita-cerita keagamaan lebih banyak menggunakan media upperground/mainstream, diterbitkan oleh penerbit besar dan didistribusikan melalui jalur 'normal', yaitu toko buku.

\subsubsection{Penokohan}

Jones (1968) memberikan definisi penokohan sebagai pelukisan gambaran yang jelas tentang seseorang yang ditampilkan dalam cerita [2]. Istilah 'tokoh' mengacu pada pelaku cerita tersebut. Watak, perwatakan, dan karakter menunjuk pada sifat dan sikap para tokoh seperti yang akan ditafsirkan oleh pembaca. Karakterisasi sendiri menitikberatkan pada penempatan tokoh-tokoh tertentu dengan watak-watak tertentu dalam sebuah cerita.

Komik sebagai bentuk karya fiksi kreatif tak lepas dari pentingnya tokoh-tokoh ceritanya. Komik menawarkan model kehidupan yang dialami tokoh-tokoh cerita sesuai dengan pandangan pengarang tentang kehidupan itu sendiri. Tokoh cerita menempati posisi strategis sebagai pembawa dan penyampai pesan, amanat, moral, atau sesuatu yang sengaja ingin disampaikan kepada pembaca.

Kategorisasi penokohan dalam penelitian ini akan menitikberatkan kepada kelas sosial dalam masyarakat. Namun demikian, karena adanya tokoh-tokoh sentral yang dominan dalam komik-komik fotokopian Indonesia 1998 - 2001 yang bukan berwujud manusia, mereka juga akan diikutsertakan dalam kategorisasi ini. 
Tabel 3 Perbandingan jumlah tokoh dan kelas sosial dalam komik fotokopian Indonesia 1998 - 2001.

\begin{tabular}{|c|c|c|c|c|c|c|}
\hline $\begin{array}{c}\text { Tokoh/ } \\
\text { Kelas }\end{array}$ & 1998 & 1999 & 2000 & 2001 & $\begin{array}{c}\text { Antara } \\
1998-2001\end{array}$ & Total \\
\hline $\begin{array}{c}\text { Laki-laki/ } \\
\text { bawah }\end{array}$ & $\begin{array}{c}11 \\
(10.28 \%)\end{array}$ & $8(5.10 \%)$ & $1(1.18 \%)$ & $5(6.58 \%)$ & $5(3.57 \%)$ & $\begin{array}{c}30 \\
(5.31 \%)\end{array}$ \\
\hline $\begin{array}{l}\text { Laki-laki/ } \\
\text { menengah }\end{array}$ & $\begin{array}{c}29 \\
(27.10 \%)\end{array}$ & $\begin{array}{c}37 \\
(23.57 \%)\end{array}$ & $\begin{array}{c}28 \\
(32.94 \%)\end{array}$ & $25(32.89 \%)$ & $30(21.43 \%)$ & $\begin{array}{c}149 \\
(26.37 \%)\end{array}$ \\
\hline $\begin{array}{c}\text { Laki- } \\
\text { laki/atas }\end{array}$ & $\begin{array}{c}11 \\
(10.28 \%)\end{array}$ & $\begin{array}{c}16 \\
(10.19 \%)\end{array}$ & $\begin{array}{c}10 \\
(11.76 \%)\end{array}$ & $6(7.89 \%)$ & $17(12.14 \%)$ & $\begin{array}{c}60 \\
(10.62 \%)\end{array}$ \\
\hline $\begin{array}{c}\text { Laki- } \\
\text { laki/tidak } \\
\text { diketahui }\end{array}$ & $9(8.41 \%)$ & $\begin{array}{c}20 \\
(12.74 \%)\end{array}$ & $\begin{array}{c}10 \\
(11.76 \%)\end{array}$ & $12(15.79 \%)$ & $17(12.14 \%)$ & $\begin{array}{c}68 \\
(12.04 \%)\end{array}$ \\
\hline $\begin{array}{l}\text { Perempuan/ } \\
\text { bawah }\end{array}$ & $2(1.87 \%)$ & $2(1.27 \%)$ & $2(2.35 \%)$ & $5(6.58 \%)$ & $1(0.71 \%)$ & $\begin{array}{c}12 \\
(2.12 \%)\end{array}$ \\
\hline $\begin{array}{l}\text { Perempuan/ } \\
\text { menengah }\end{array}$ & $\begin{array}{c}18 \\
(16.82 \%)\end{array}$ & $\begin{array}{c}17 \\
(10.83 \%)\end{array}$ & $\begin{array}{c}14 \\
(16.47 \%)\end{array}$ & $10(13.16 \%)$ & $8(5.71 \%)$ & $\begin{array}{c}67 \\
(11.86 \%)\end{array}$ \\
\hline $\begin{array}{l}\text { Perempuan/ } \\
\text { atas }\end{array}$ & $5(4.67 \%)$ & $\begin{array}{c}10 \\
(6.37 \%)\end{array}$ & $\begin{array}{c}11 \\
(12.94 \%)\end{array}$ & $4(5.26 \%)$ & $29(20.71 \%)$ & $\begin{array}{c}59 \\
(10.44 \%)\end{array}$ \\
\hline $\begin{array}{c}\text { Perempuan/ } \\
\text { tidak } \\
\text { diketahui }\end{array}$ & $4(3.74 \%)$ & $4(2.55 \%)$ & $1(1.18 \%)$ & $4(5.26 \%)$ & $4(2.86 \%)$ & $\begin{array}{c}17 \\
(3.01 \%)\end{array}$ \\
\hline Hewan & $3(2.80 \%)$ & $\begin{array}{c}25 \\
(15.92 \%)\end{array}$ & $2(2.35 \%)$ & $3(3.95 \%)$ & $5(3.57 \%)$ & $\begin{array}{c}38 \\
(6.73 \%)\end{array}$ \\
\hline Lain-lain & $\begin{array}{c}15 \\
(14.02 \%) \\
\end{array}$ & $\begin{array}{c}18 \\
(11.46 \%) \\
\end{array}$ & $6(7.06 \%)$ & $2(2.63 \%)$ & $24(17.14 \%)$ & $\begin{array}{c}65 \\
(11.50 \%) \\
\end{array}$ \\
\hline Total & $\begin{array}{c}107 \\
(100 \%)\end{array}$ & $\begin{array}{c}157 \\
(100 \%)\end{array}$ & $\begin{array}{c}85 \\
(100 \%)\end{array}$ & $76(100 \%)$ & $140(100 \%)$ & $\begin{array}{c}565 \\
(100 \%)\end{array}$ \\
\hline
\end{tabular}

Dari hasil penelitian tersebut di atas, tampak bahwa tokoh lelaki dari kelas menengah amat dominan. Biasanya tokoh ini direpresentasikan dalam bentuk siswa sekolah menengah dan mahasiswa, dengan problematikanya sehari-hari. Tokoh lelaki yang tidak dapat diidentifikasi kelasnya biasanya merupakan tokoh pendekar. Pemilihan tokoh lelaki bisa jadi merefleksikan pengetahuan komikus atas masalah-masalah yang dihadapinya, termasuk masalah sosial, psikologis, dan ideologis.

Tokoh hewan dan makhluk lainnya pun tampak cukup dominan. Hewan di sini bisa berarti hewan nyata atau hewan khayalan. Demikian juga dengan jenis tokoh lain yang amat bervariasi: makhluk halus/gaib/supranatural, alien dari luar bumi, robot, bahkan alat kontrasepsi. Tokoh-tokoh non manusia ini digunakan sebagai personifikasi untuk menyampaikan pesan-pesan dalam kehidupan manusia sehar-hari, yang biasanya merupakan sindiran/black comedy. 


\subsubsection{Latar}

Abrams (1981) mendefinisikan latar atau setting sebagai tempat, hubungan waktu, dan lingkungan sosial tempat terjadinya peristiwa-peristiwa yang diceritakan [2]. Latar memberikan landasan cerita secara konkrit, memberikan kesan realistis kepada pembaca, dan menciptakan suasana tertentu yang seakanakan benar-benar terjadi.

Unsur latar dapat dibedakan menjadi latar tempat, latar waktu, dan latar sosial (pada hal-hal yang berhubungan dengan perilaku kehidupan sosial di suatu tempat yang diceritakan tersebut). Pada kesempatan ini, penulis hanya akan menelaah latar tempat dan latar waktu dalam tabel-tabel sebagai berikut.

\subsubsection{Latar Tempat: Mengacu pada Lokasi Terjadinya Peristiwa yang Diceritakan}

Tabel 4 Perbandingan latar tempat dalam komik fotokopian Indonesia 1998 2001.

\begin{tabular}{|c|c|c|c|c|c|c|}
\hline Tempat & 1998 & 1999 & 2000 & 2001 & 1998 - 2001 & Total \\
\hline Kota & $33(53.23 \%)$ & $\begin{array}{c}44 \\
(52.38 \%)\end{array}$ & $31(68.89 \%)$ & $31(59.62 \%)$ & $53(69.74 \%)$ & $\begin{array}{c}192 \\
(60.19 \%)\end{array}$ \\
\hline Desa & $6(9.68 \%)$ & $\begin{array}{c}7 \\
(8.33 \%)\end{array}$ & $5(11.11 \%)$ & $13(25.00 \%)$ & $2(2.63 \%)$ & $\begin{array}{c}33 \\
(10.34 \%)\end{array}$ \\
\hline $\begin{array}{l}\text { Lain- } \\
\text { lain }\end{array}$ & $23(37.10 \%)$ & $\begin{array}{c}33 \\
(39.29 \%) \\
\end{array}$ & $9(20.00 \%)$ & $8(15.38 \%)$ & $21(27.63 \%)$ & $\begin{array}{c}94 \\
(29.47 \%)\end{array}$ \\
\hline Total & $62(100 \%)$ & $\begin{array}{c}84 \\
(100 \%)\end{array}$ & $45(100 \%)$ & $52(100 \%)$ & $76(100 \%)$ & $\begin{array}{c}319 \\
(100 \%)\end{array}$ \\
\hline
\end{tabular}

\subsubsection{Latar Waktu: Berurusan dengan Kapan Terjadinya Cerita Tersebut}

Tabel 5 Perbandingan latar waktu dalam komik fotokopian Indonesia 1998 2001.

\begin{tabular}{|c|c|c|c|c|c|c|}
\hline Masa & 1998 & 1999 & 2000 & 2001 & $\begin{array}{c}1998- \\
2001 \\
\end{array}$ & Total \\
\hline Lalu & $7(10.94 \%)$ & $6(6.90 \%)$ & $6(12.77 \%)$ & $10(19.23 \%)$ & $4(5.33 \%)$ & $\begin{array}{c}33 \\
(10.15 \%)\end{array}$ \\
\hline Kini & $37(57.81 \%)$ & $\begin{array}{c}53 \\
(60.92 \%)\end{array}$ & $29(61.70 \%)$ & $32(61.54 \%)$ & $\begin{array}{c}44 \\
(58.67 \%)\end{array}$ & $\begin{array}{c}195 \\
(60.00 \%)\end{array}$ \\
\hline Depan & $5(7.81 \%)$ & $7(8.05 \%)$ & $6(12.77 \%)$ & $5(9.62 \%)$ & $\begin{array}{c}9 \\
(12.00 \%)\end{array}$ & $32(9.85 \%)$ \\
\hline $\begin{array}{c}\text { Lain- } \\
\text { lain }\end{array}$ & $15(23.44 \%)$ & $\begin{array}{c}21 \\
(24.14 \%) \\
\end{array}$ & $6(12.77 \%)$ & $5(9.62 \%)$ & $\begin{array}{c}18 \\
(24.00 \%) \\
\end{array}$ & $\begin{array}{c}65 \\
(20.00 \%) \\
\end{array}$ \\
\hline Total & $64(100 \%)$ & $\begin{array}{c}87 \\
(100 \%)\end{array}$ & $47(100 \%)$ & $52(100 \%)$ & $\begin{array}{c}75 \\
(100 \%) \\
\end{array}$ & $325(100 \%)$ \\
\hline
\end{tabular}


Berdasarkan tabel di atas, tampak bahwa kebanyakan latar komik Indonesia fotokopian tahun 1998 - 2001 mengambil setting kota di masa kini. Latar tempat yang juga cukup dominan adalah tempat selain kota dan desa, yaitu hutan, kerajaan, negeri antah berantah, planet atau dimensi lain, bahkan alam gaib. Sementara latar waktu yang juga dominan adalah masa lain, dalam hal ini tidak terikat oleh waktu secara kronologis. Biasanya kurun waktu ini merupakan kombinasi antara masa lalu, masa kini, dan masa depan.

\subsubsection{Raga Komik: Ilustrasi}

Sebagai penyampai informasi utama, ilusrasi merupakan unsur dominant dalam komik. Ilusrasi dalam komik dikatakan komunikatif bila mampu menyampaikan keutuhan cerita, menunjukkan urutan kejadian, membangkitkan emosi, dan menciptakan suasana. Meskipun dalam komik unsur verbal dan visual tidak dapat dipisahkan, namun tidak dapat dipungkiri bahwa ilustrasi masih menjadi kekuatan utama.

Mengingat pentingnya kedudukan ilustrasi dalam komik, sebelum narasi atau dialog mengungkapkan cerita secara lebih jauh, ilustrasi harus mampu 'bercerita' melalui visualisasi gerak, ekspresi, latar, dan situasi, karena hal-hal seperti ini tidak dapat disampaikan secara tepat hanya dengan melalui narasi. Pada awalnya, ilustrasi menjadi daya tarik bagi orang untuk membaca komik, dan selanjutnya daya tarik lebih ditentukan oleh kelancaran penyampaian cerita dan susunan cerita.

Tabel 6 Perbandingan pengaruh gaya visual dalam komik fotokopian Indonesia 1998 - 2001.

\begin{tabular}{|c|c|c|c|c|c|c|}
\hline $\begin{array}{c}\text { Pengaruh } \\
\text { Gaya Visual }\end{array}$ & 1998 & 1999 & 2000 & 2001 & 1998 - 2001 & Total \\
\hline Amerika & $\begin{array}{c}14 \\
(22.58 \%)\end{array}$ & $13(14.94 \%)$ & $\begin{array}{c}13 \\
(18.06 \%)\end{array}$ & $\begin{array}{c}6 \\
(11.32 \%)\end{array}$ & $20(17.86 \%)$ & $\begin{array}{c}66 \\
(17.10 \%)\end{array}$ \\
\hline Jepang & $\begin{array}{c}21 \\
(33.87 \%)\end{array}$ & $21(24.14 \%)$ & $\begin{array}{c}38 \\
(52.78 \%)\end{array}$ & $\begin{array}{c}27 \\
(50.94 \%)\end{array}$ & $44(39.29 \%)$ & $\begin{array}{c}151 \\
(39.12 \%)\end{array}$ \\
\hline Eropa & $\begin{array}{c}8 \\
(12.90 \%)\end{array}$ & $8(9.20 \%)$ & $\begin{array}{c}12 \\
(16.67 \%)\end{array}$ & $\begin{array}{c}6 \\
(11.32 \%)\end{array}$ & $17(15.18 \%)$ & $\begin{array}{c}51 \\
(13.21 \%)\end{array}$ \\
\hline Lain-lain & $\begin{array}{c}19 \\
(30.65 \%) \\
\end{array}$ & $45(51.72 \%)$ & $\begin{array}{c}9 \\
(12.50 \%) \\
\end{array}$ & $\begin{array}{c}14 \\
(26.42 \%) \\
\end{array}$ & $31(27.68 \%)$ & $\begin{array}{c}118 \\
(30.57 \%) \\
\end{array}$ \\
\hline Total & $\begin{array}{c}62 \\
(100 \%) \\
\end{array}$ & $87(100 \%)$ & $\begin{array}{c}72 \\
(100 \%) \\
\end{array}$ & $\begin{array}{c}53 \\
(100 \%) \\
\end{array}$ & $112(100 \%)$ & $\begin{array}{c}386 \\
(100 \%) \\
\end{array}$ \\
\hline
\end{tabular}

Ilustrasi erat kaitannya dengan gaya visual. Seperti telah disebutkan di atas, saat ini diasumsikan terdapat dua aliran utama yang mendominasi komik modern Indonesia, yaitu gaya komik Amerika yang identik dengan gaya super hero nan berotot, dan gaya Jepang dengan karakter kartun ber-background realistis. Gaya lain yang nampak muncul, walau tidak sedominan dua gaya tersebut, ialah gaya 
Eropa yang menggambarkan karakter cenderung 'bersih' dan ikonik, namun menampilkan latar belakang dengan detail.

Tabel 6 menampilkan pengaruh gaya visual yang digunakan oleh komikus dalam membuat komik fotokopian Indonesia tahun 1998 - 2001.

Tampak bahwa ternyata selain pengaruh visual manga, gaya visual lainnya pun cukup dominan bila dibandingkan dengan gaya visual Amerika maupun Eropa. Gaya visual lain ini sangat bermacam-macam dan eksperimental, tak jarang menggabungkan lebih dari satu gaya visual dalam satu karya komik fotokopian.

\subsubsection{Kesimpulan Umum}

Jika konteks internal komik fotokopian Indonesia 1998 - 2001 ditinjau secara keseluruhan, tampak bahwa tema sosial (50.98\%) dan tema batin (49.02\%) tidak saling mendominasi, namun saling melengkapi satu sama lain. Dari segi cerita, komik-komik dengan cerita humor amat dominan bila dibandingkan dengan yang lainnya (20.43\%). Jika kota menempati posisi tertinggi dari segi latar tempat (60.19\%), maka dari segi latar waktu masa kini mendominasi (60.00\%). Secara visual, pengaruh gaya manga Jepang masih kental (39.12\%) bila dibandingkan dengan gaya visual Amerika dan Eropa. Namun demikian, gaya visual alternative / lain-lain pun cukup dominan (30.57\%).

\section{$5 \quad$ Konteks Eksternal Komik Fotokopian Indonesia}

\section{$5.1 \quad$ Komikus}

Dari total 108 komik fotokopian yang diteliti, seluruhnya (100\%) dikerjakan oleh komikus yang berstatus sebagai mahasiswa. Penelitian ini akan mencoba untuk melihat kota domisili komikus, sebagaimana tercantum dalam komik karyanya, dan jenis kelamin mereka.

\subsection{Kota Domisili Komikus}

Tabel 7 Perbandingan kota domisili komikus komik fotokopian Indonesia 1998 - 2001.

\begin{tabular}{|c|c|c|c|c|c|c|}
\hline Kota & 1998 & 1999 & 2000 & 2001 & $1998-2001$ & Total \\
\hline Jakarta & $\begin{array}{c}46 \\
(77.97 \%)\end{array}$ & $\begin{array}{c}72 \\
(58.06 \%)\end{array}$ & $49(71.01 \%)$ & $19(40.43 \%)$ & $46(57.50 \%)$ & $\begin{array}{c}232 \\
(61.21 \%)\end{array}$ \\
\hline Bandung & $\begin{array}{c}13 \\
(22.03 \%)\end{array}$ & $\begin{array}{c}47 \\
(37.90 \%)\end{array}$ & $12(17.39 \%)$ & $13(27.66 \%)$ & $15(18.75 \%)$ & $\begin{array}{c}100 \\
(26.39 \%)\end{array}$ \\
\hline Lain-lain & $0(0 \%)$ & $5(4.03 \%)$ & $8(11.59 \%)$ & $15(31.91 \%)$ & $19(23.75 \%)$ & $\begin{array}{c}47 \\
(12.40 \%)\end{array}$ \\
\hline Total & $59(100 \%)$ & $\begin{array}{c}124 \\
(100 \%)\end{array}$ & $69(100 \%)$ & $47(100 \%)$ & $80(100 \%)$ & $379(100 \%)$ \\
\hline
\end{tabular}




\subsubsection{Jenis Kelamin Komikus}

Tabel 8 Perbandingan jenis kelamin komikus komik fotokopian Indonesia $1998-2001$.

\begin{tabular}{|c|c|c|c|c|c|c|}
\hline $\begin{array}{c}\text { Jenis } \\
\text { Kelamin }\end{array}$ & 1998 & 1999 & 2000 & 2001 & $1998-2001$ & Total \\
\hline Laki-laki & $\begin{array}{c}58 \\
(98.31 \%)\end{array}$ & $\begin{array}{c}110 \\
(88.71 \%)\end{array}$ & $\begin{array}{c}52 \\
(75.36 \%)\end{array}$ & $37(78.72 \%)$ & $70(87.50 \%)$ & $\begin{array}{c}327 \\
(86.28 \%)\end{array}$ \\
\hline Perempuan & $\begin{array}{c}1 \\
(1.69 \%)\end{array}$ & $14(11.29 \%)$ & $\begin{array}{c}15 \\
(21.74 \%)\end{array}$ & $9(19.15 \%)$ & $10(12.50 \%)$ & $\begin{array}{c}49 \\
(12.93 \%)\end{array}$ \\
\hline $\begin{array}{c}\text { Tidak } \\
\text { teridentifikasi }\end{array}$ & $0(0 \%)$ & $0(0 \%)$ & $2(2.90 \%)$ & $1(2.13 \%)$ & $0(0 \%)$ & $3(0.79 \%)$ \\
\hline Total & $\begin{array}{c}59 \\
(100 \%) \\
\end{array}$ & $124(100 \%)$ & $\begin{array}{c}69 \\
(100 \%)\end{array}$ & $47(100 \%)$ & $80(100 \%)$ & $\begin{array}{c}379 \\
(100 \%)\end{array}$ \\
\hline
\end{tabular}

Jumlah komikus yang ikut berpartisipasi dalam pembuatan 108 judul komik fotokopian Indonesia tahun 1988 - 2001 adalah sebanyak 379 orang. Jakarta merupakan kota domisili komikus dengan angka terbanyak (61.21\%), yaitu hampir sepertiga dari jumlah komikus secara keseluruhan. Selain Bandung, domisili komikus yang tercatat di sini adalah kota-kota Solo, Yogyakarta, Bogor, Malang, Bekasi, dan Surabaya.

Dari sisi jenis kelamin, tampak jelas bahwa secara keseluruhan komikus lakilaki amat dominan (86.28\%). Hal menarik adalah terdapatnya komikus yang tidak dapat diidentifikasi jenis kelaminnya, apakah ia laki-laki atau perempuan. Hal ini dikarenakan ketidakjelasan penanda yang diberikan oleh komikus tersebut, sementara gaya visual tidak dapat dijadikan acuan untuk menentukan jenis kelamin komikus.

\subsection{Produksi dan Distribusi}

Biasanya komik-komik fotokopian ini diproduksi dengan cara memanfaatkan jasa layanan fotokopi yang tersebar di seluruh penjuru kota. Komikus membuat sebuah master untuk kemudian diperbanyak. Bahkan tidak sedikit komikus yang memproduksi karyanya dalam jumlah terbatas, dan mempersilahkan pembaca untuk memperbanyaknya sendiri. Tidak jarang pula komik-komik ini disertai bonus seperti misalnya stiker.

Konsep produksi dengan fotokopi menjadi ciri khas tersendiri bagi komikkomik ini, yang bahkan bisa diterapkan sebagai sebuah bentuk seni yang masih bisa dieksplorasi lebih jauh lagi. Fotokopi telah menjadi seni yang praktis, relatif murah dan bisa dijangkau oleh siapa saja.

Distribusi komik-komik ini dilakukan dengan cara barter dan direct selling. Para komikus yang 'memberontak' terhadap 'hegemoni' toko buku 
memanfaatkan event-event dan acara-acara komik - bahkan musik - untuk menjual karya-karyanya. Website dan internet pun menjadi sarana penjualan yang efektif dan efisien. Meskipun diproduksi dalam jumlah terbatas, komikkomik ini biasanya cepat habis terjual karena telah mempunyai penggemar fanatiknya masing-masing.

Sebagai konsekuensinya, komik-komik ini hanya beredar di kalangan terbatas. Jumlah eksemplar yang terbatas pun membuatnya relative sulit untuk didapat. Namun demikian, ada kepuasan tersendiri jika berhasil memperolehnya terutama bagi para penggemar fanatik salah satu judul atau karya kelompok komik tertentu.

\subsection{Pembaca}

Tak dapat dipungkiri bahwa pembaca komik merupakan faktor penting dalam industri komik secara keseluruhan, bahkan bisa jadi proses memenuhi keinginan atau selera pembaca dapat membentuk karakter dan identitas dari komik itu sendiri. Pengetahuan mendalam akan karakter pembaca akan menghasilkan komik-komik yang lebih fokus untuk satu golongan pembaca yang lebih khusus/spesifik. Hal ini sedikit banyak akan berpengaruh dalam proses kreatif pembuatan komik itu sendiri, di mana komik dibuat sebagai solusi untuk target audience tertentu.

Dalam tulisannya Belajar Memahami Pembaca Komik di Indonesia seperti yang Dilakukan Negara-Negara Lain yang dimuat dalam kumpulan tulisan Komik Asia 2005 lalu, Hengky Hidayat [4] mengungkapkan tentang pentingnya para pembaca komik ini sebagai berikut:

Walaupun pembaca komik di Indonesia mungkin belum banyak jika dibandingkan dengan jumlah penduduk Indonesia, namun jumlah pembaca komik ini masih terus meningkat dan pada akhirnya merekalah pihak yang menentukan akan dibawa ke mana arah komik Indonesia. Karena dengan semakin banyaknya komik yang terbit dan beredar, maka akan semakin berhatihati pula pembaca di dalam menentukan komik yang akan mereka beli. Dengan demikian, mereka akan memiliki selera sendiri di dalam menentukan pilihan mereka, tanpa bisa dipengaruhi baik lehkomikus maupun penerbit.

Pembaca akan semakin tersegmentasi, baik dalam hal usia maupun selera. Karena itu dharapkan komikus dapat dengan jeli menangkap trend komik yang sedang digemari, dan bahkan bukanlah tidak mungkin pada suatu hari nanti akan mampu menciptakan trend bagi pembaca komik di Indonesia. Dengan berbagai media yang ada (internet) serta acara-acara komik, akan terbuka banyak kesempatan untuk dapat mempertemukan komikus dengan pembaca, 
sehingga komikus dapat secara langsung mengetahui pendapat dan keinginan dari pembaca komik.

Masih sangat panjang perjalanan komik Indonesia, demikian pula masih akan banyak peluang yang muncul untuk mengisi setiap ceruk yang tercipta. Misalnya, para pembaca komik sekarang pasti akan bertambah dewasa, dan pada saatnya nanti akan tercipta genre bagi orang dewasa.

Alvanov Zpalanzani, Hafiz Ahmad, dan Beny Maulana dalam bukunya Histeria! Komikita: Membedah Komikita Masa Lalu, Sekarang, dan Masa Depan [5] membagi jenis pembaca komik ke dalam 3 golongan dengan karakternya masing-masing:

\subsubsection{Pembaca Golongan Kritis: 'Pengamat' Komikita}

Jenis pembaca yang rajin mengevaluasi komik dari berbagai aspek, dan memberikan masukan bahkan resensi serta penilaian. Meskipun relatif kritis, pembaca jenis ini tidak selalu membeli komik yang mereka kritisi. Kritik-kritik yang cenderung terlalu tajam - bahkan kadang sampai memaki-maki dan menghujat - pun bisa berpotensi untuk memadamkan kreativitas komikus.

\subsubsection{Pembaca Wanita: 'Sinergi' dari Hati ke Hati}

Jenis pembaca yang relatif lebih mengutamakan kedekatan cerita kehidupan sehari-hari sebagai bentuk ekspresi bertutur dari hati ke hati antara komikus dengan pembacanya. Aspek visual yang stylist dan storytelling yang intim membuat terjadinya jalinan emosional, sebagai target pasar yang jumlahnya amat banyak secara kuantitatif dan relatif fanatik secara kualitatif.

\subsubsection{Pembaca 'Diam': Potential Buyer}

Jenis pembaca yang tidak banyak menuntut ini itu dari sebuah komik, namun rajin membelinya. Bisa jadi mayoritas dari segi jumlah, namun sulit untuk diketahui.

Dapat dikatakan bahwa karakter pembaca komk-komik fotokopian Indonesia merupakan kombinasi dari karakter-karakter tersebut. Fanatisme membuat mereka rajin mengunjungi event-event komik agar bisa membeli langsung komik-komik yang memang terbatas jumlahnya tersebut. Mereka juga rajin memberikan evaluasi, dan merasakan kedekatan emosional dengan komikkomik tersebut. Mereka merasakan kenikmatan tersendiri saat membeli komik tidak di toko buku, melainkan langsung dari komikusnya saat event-event komik. Mereka juga merasakan kebanggaan tersendiri saat memiliki komik edisi terbatas yang tidak dimiliki oleh orang lain. 
Berdasarkan pengamatan penulis, kebanyakan pembaca komik-komik fotokopian ini sebagian besar adalah mahasiswa, yang notabene merupakan teman-teman komikus dan sesama komikus. Selain mahasiswa, sepertinya tidak sedikit juga para pelajar sekolah menengah dan para pengamat yang menjadi pembacanya. Namun demikian - sekali lagi, sepengetahuan penulis - rasanya belum ada penelitian yang memetakan pembaca komik - khususnya komikkomik indie/underground ini secara komprehensif. Tentunya penelitian lebih lanjut dan mendalam tentang hal ini akan sangat bermanfaat.

\subsubsection{Kesimpulan Umum}

Hasil tinjauan secara keseluruhan mengenai konteks eksternal komik fotokopian Indonesia tahun 1998 - 2001 menunjukkan bahwa sebagian besar komikus berdomisili di Jakarta (61.21\%), sementara tampak dari segi jumlah bahwa komikus laki-laki pun amat dominan (86.28\%) jika dibandingkan dengan komikus perempuan.

Sebagaimana diistilahkan, komik fotokopian Indonesia tahun 1998 - 2001 diproduksi dalam jumlah terbatas dengan memanfaatkan jasa layanan fotokopi, dan didistribusikan dalam ruang lingkup terbatas pula dengan cara barter serta penjualan langsung pada acara-acara komik.

Berdasarkan pengamatan sementara, pembaca komik fotokopian Indonesia tahun 1998 - 2001 kebanyakan berstatus mahasiswa dan pelajar, dengan karakter yang relatif kritis, fanatik, dan terbuka terhadap perubahan. Namun demikian, kiranya perlu dilakukan penelitian lebih lanjut dan mendalam tentang hal ini.

\section{Menuju Masa Depan 'Komik Keindonesiaan”}

\subsection{Mencari Identitas Komik Indonesia}

Sebagai cerminan dari kehidupan masyarakat, komik mengandung nilai-nilai yang senantiasa tumbuh dan berkembang seiring dengan perkembangan masyarakat itu sendiri. 'Jiwa' dan 'raga' komik sebagai unsur intrinsik pun tidak dapat lepas dari hal-hal yang mempengaruhi unsur ekstrinsiknya. Nilai bentuk dan nilai isi keduanya tidak dapat dipisahkan karena keduanya merupakan perpaduan yang utuh dan solid. Perpaduan inilah yang menciptakan identitas komik itu sendiri.

Dalam ruang lingkup Sosiologi, persoalan identitas ini menjadi penting, karena:

- Adanya kecenderungan untuk membandingkan produk dalam negeri (dalam hal ini, komik) dengan produk luar 
- Adanya keinginan untuk memiliki komik Indonesia dengan berkarakter yang 'berbeda', yang mampu dibanggakan.

- Adanya kemudahan untuk membandingkan komik Indonesia dengan komik yang saat ini sedang menjadi trend

Yang sering dianggap sebagai 'cetak biru' komik Indonesia (modern) adalah komik-komik Indonesia pada masa jayanya, yaitu tahun 1960-an hingga 1970an. Tidak diragukan lagi bahwa memang pada masa tersebut, komik-komik Indonesia amat layak untuk disandingkan - bahkan bisa menandingi - komikkomik impor sezamannya. Kandungan nilai-nilai positif dan unsur lokalnya amat pantas untuk diketahui oleh generasi-generasi selanjutnya. Dengan demikian, tidak heran jika tampilan visual romantisme klasik tersebut sering menjadi acuan bahwa memang demikianlah tampilan komik Indonesia.

Bagaimanapun juga, rasanya terlalu naif bila kita langsung 'menghakimi' bahwa hanya itulah wajah komik Indonesia. Kita seakan mengingkari kenyataan bahwa identitas komik pun senantiasa berkembang, berubah sesuai dengan perubahan zaman. Bahkan pada masa tersebut, sebenarnya pengaruh komikkomik luar - terutama komik silat Cina dan komik adi ksatria Amerika - amat terasa. Namun demikian, satu hal yang patut digarisbawahi adalah muatan lokal yang tidak dilupakan oleh para komikus masa tersebut. Meski tampilan visual mengadaptasi komik luar, namun unsur lokal yang dimasukkan oleh para komikus senior ini mampu menyatu dalam cerita secara integral. Hal ini bisa menjadi pelajaran untuk para komikus masa kini.

Seringkali kita lupa, bahwa komik - sebagai produk budaya - merupakan hasil perpaduan/serapan dari berbagai pengaruh yang ada. Kebudayaan, sebagai segala sesuatu yang dilahirkan manusia setelah melalui proses pembelajaran, memiliki 4 kriteria, yaitu:

- Tradisional: disepakati oleh masyarakat dan diwariskan;

- Modern: diwariskan dengan sedikit banyak berubah;

- Mengikat waktu: proses berkesinambungan dari masa lalu, masa kini, dan masa depan; serta

- Berbeda - beraneka - integral: memiliki perbedaan nilai karena refleksi dan adaptif terhadap lingkungan

Banyak orang terjebak pada penafsiran bahwa budaya adalah sesuatu yang sifatnya tradisional. Padahal sesuai definisinya, budaya merupakan proses belajar. Dalam romantisme komik Indonesia tahun 1960-an hingga 1970-an, para komikus senior menerapkan proses belajar tersebut. Langkah selanjutnya setelah belajar dari 'luar' adalah mengadaptasikan apa yang didapat dengan lingkungan Indonesia melalui cara bertutur, pola pikir, dan situasi serta kondisi lokal. Tidak heran jika mereka menjadi 'legenda'. 
Hikmat Darmawan [6], salah seorang pemerhati komik, berpendapat bahwa sebaiknya isu identitas ini ditinjau dari dua sudut pandang:

- Identitas sang komikus, sebagai proses penemuan jati diri dan ciri khas yang berpengaruh pada karya-karyanya; dan

- Identitas media suatu negara, yang sifatnya multidimensional dan tidak bisa dikaji secara sepintas hanya dari unsur visual saja

Kedua jenis identitas ini pun tentunya harus ditinjau dengan pendekatan yang berbeda secara arif dan bebas prasangka, bukan 'dipaksa' atau terbatas hanya menggunakan satu sudut pandang saja, apalagi dengan prasangka buruk. Seiring dengan berkembangnya teknologi informasi, tentunya proses kreatif yang mempengaruhi unsur intrinsik dan ekstrinsik komik pun mengalami perkembangan pula.

Tak dapat disangkal bahwa identitas amat penting, namun jika kita terjebak hanya dengan perdebatan seputar isu identitas tersebut, bisa jadi malah menjadi kontra produktif dengan perkembangan komik Indonesia itu sendiri. Bagaimana mungkin sebuah identitas muncul jika tidak 'dicari' melalui karya yang terus menerus? Apa pun yang dilakukan, sebagaimana halnya komikus-komikus senior terdahulu sudah pernah melakukannya, membutuhkan waktu dan proses. Karya-karya komikus terdahulu amat layak dibaca dan diapresiasi sebagai memorabilia, karena sudah tidak lagi merupakan representasi masa kini.

Perlu dicatat bahwa generasi komikus fotokopian Indonesia tahun 1998 - 2001 ini adalah generasi yang bersifat lebih universal dan tidak identik dengan satu budaya (visual) tertentu. Berbeda dengan para seniornya, mereka membuat komik berdasarkan keinginan untuk 'menangkap' apa yang menjadi perhatiannya dan mengekspresikannya lewat media komik. Isu identitas belum - atau bahkan tidak - menjadi prioritas utama. Oleh karena itulah mereka membutuhkan proses (berkarya) dalam menemukan jati diri mereka. Identitas adalah sesuatu yang didapat, bukan sengaja dicari. Alvanov Zpalanzani, Hafiz Ahmad, dan Beny Maulana mendefinisikan komik Indonesia (dalam istilah mereka: komikita) sebagai komik buatan orang Indonesia, yang diterbitkan juga di Indonesia [5]. Pada akhirnya, seperti kata Machiko Maeyama (salah seorang mangaka yang saat ini tinggal di Indonesia), sebagaimana dikutip dalam buku Histeria! Komikita: Membedah Komikita Masa Lalu, Sekarang, dan Masa Depan, diharapkan akan terbentuk sebuah identitas komik Indonesia: komik yang hanya bisa dihasilkan oleh orang Indonesia sendiri.

\subsection{Proyeksi Komik Indonesia di Masa Depan}

Hingga saat ini, dunia perkomikan di Indonesia secara keseluruhan masih berusaha untuk dikelola secara profesional dari segi produksi maupun 
pemasarannya. Profesionalisme sedang berusaha dicapai melalui pendekatan industri dengan komik sebagai hasil sinergi kreatif kolektif. Dengan melihat gejala kebangkitan kembali komik Indonesia dengan pendekatan industrialisasi ini, dapat dikatakan bahwa prospek komik lokal sebagai komoditi dalam negeri cukup cerah. Hal ini didukung dengan berkembangnya sumber daya manusia berupa komikus-komikus generasi baru. Bahkan beberapa di antara mereka aktif terlibat dalam pembuatan komik lintas negara, dengan visualisasi yang tidak kalah dengan komik impor.

Diperkirakan dengan banyaknya kelompok-kelompok produksi komik dan meningkatnya perhatian serta apresiasi masyarakat Indonesia terhadap komik lokal, komik Indonesia akan terus tumbuh dan berkembang. Munculnya komik yang menampilkan sesuatu yang baru akan menarik minat pembaca dan berperan besar dalam perkembangan pasar komik Indonesia. Oleh karena itu, diharapkan para komikus muda lebih memperhatikan aspek cerita - terutama kandungan muatan lokal - dalam karya mereka. Di sisi lain, kehadiran komik asing tetap diperlukan sebagai bahan perbandingan.

Idealnya, kebangkitan komik Indonesia major label/mainstream dan indie/ underground bisa seiring sejalan. Jika hanya komik mainstream saja yang berusaha bangkit, berwajah visual ala Jepang, Amerika, dan Eropa, dengan alasan kompromi kepada selera pasar, kita akan semakin jauh dari identitas yang ingin dicapai tanpa muatan lokal. Muatan lokal yang kental dikemas dalam komik-komik indie / underground dan identik dengan teknik produksi via mesin fotokopi sebagai alat ekspresi bebas pun selayaknya bergerak di luar kecerobohan dan asal-asalan. Bisa jadi hal ini mengakibatkan orang (awam) malah takut akan kehadiran komik Indonesia dan komik pada umumnya.

Semangat menampik 'hegemoni' mainstream hendaknya disalurkan dengan wajar dan benar. Buktinya karya-karya Eko Nugroho - presiden komunitas komik The Daging Tumbuh, salah satu ikon komik underground dari Yogyakarta - menjadi tempat koleksi di beberapa tempat terhormat, seperti di antaranya Gallery of Modern Art (GOMA) (Brisbane, Australia), Contemporary Arts Center, (New Orleans, USA), Museum and Art Gallery of the Nothern Territory, (Darwin, Australia), Haus Der Kulturen Der Welt (Berlin, Jerman), dan Artoteek Den Haag / HEDEN (Belanda), sebagai harta karun nasional hasil karya anak bangsa Indonesia.

Dalam 10 tahun terakhir ini pun telah banyak diadakan berbagai acara seputar komik: pameran, lomba, bazaar, kursus, diskusi, dan lain sebagainya. Walaupun secara garis besar masih diadakan di seputar pulau Jawa, namun bukan tidak mungkin jika di kemudian hari diadakan di belahan Indonesia lainnya. Berbagai liputan di media massa cetak dan elektronik pun menunjukkan perhatian 
masyarakat, di samping pada saat yang sama juga membuka wawasan masyarakat tentang kondisi perkomikan Indonesia saat ini.

Seperti dikemukakan oleh Arswendo Atmowiloto, masih belum ada formula yang pas bagi komik lokal untuk menjawab tantangan industri yang telah berubah ini. Semua - komikus, penerbit, juga pembaca - masih harus mencari formula itu. Minat baca masyarakat kita yang relatif rendah pun menjadi sebuah kendala tersendiri. Dengan komik fotokopian, para komikus indie / underground mulai mengukuhkan eksistensinya dan semakin mematangkan gaya mereka dalam mencari wajah komik Indonesia yang hilang. Bagaimana mungkin kita dapat menemukan identitas komik Indonesia, jika kita sendiri tidak ikut berproses secara aktif di dalamnya?

Masih banyak yang harus kita pelajari bersama tentang komik Indonesia. Menemukan dan mendefinisikan kembali identitas komik Indonesia bukan hal yang mudah, tapi bukan hal yang tidak mungkin. Jalan menuju ke sana telah terbentuk, tinggal bagaimana menapakinya dengan dukungan berbagai pihak terkait.

Semoga komik Indonesia akan mengalami perubahan positif yang lebih signifikan dalam 10 tahun yang akan datang.

\section{Daftar Pustaka}

[1] Bonneff, Marcel. 1998. Komik Indonesia, Jakarta: Kepustakaan Populer Gramedia.

[2] Nurgiyantoro, Burhan. 1995. Teori Pengkajian Fiksi, Yogyakarta: Gadjah Mada University Press.

[3] Sumardjo, Jakob. 1999. Konteks Sosial Novel Indonesia 1920 - 1977, Bandung: Alumni.

[4] Hidayat, Hengky. 2005. Belajar Memahami Pembaca Komik di Indonesia seperti yang Dilakukan Negara-Negara Lain, Kumpulan Tulisan Komik Asia 2005: Program Studi Desain Komunikasi Visual, Departemen Desain Fakultas Seni Rupa dan Desain Institut Teknologi Bandung.

[5] Zpalanzani, Alvanov; Ahmad, Hafiz; dan Maulana, Beny. 2006. Histeria! Komikita: Membedah Komikita Masa Lalu, Sekarang, dan Masa Depan, Jakarta: PT Elex Media Komputindo.

[6] Darmawan, Hikmat. 2005. Dari Gatotkaca Hingga Batman, Yogyakarta: Orakel. 